\title{
Mechanical Properties and Sensitization Behavior of as Cast Fe-Al-Mn-xSi-C Lightweight Steel
}

\author{
Ratna Kartikasariand Sutrisna \\ Department of Mechanical Engineering, Nasional College of Technology, \\ Yogyakarta, Indonesia 55281
}

\begin{abstract}
Mechanical properties and sensitization behavior of Fe-Al-Mn-xSi-C alloys have been investigated by using tensile test, Vickers hardness test, impact test, scanning electron microscope and XRD. The aim of the research is to investigate mechanical properties and sensitization behavior of the as cast $\mathrm{Fe}$ Al-Mn-XSi-Calloys. The alloys were prepared by an induction furnace under an argon atmosphere. The results showed that the mechanical properties such as the ultimate tensile test (UTS) and elongation of these alloys were in the range (617.78-695.56 $\mathrm{MPa}$ ) and 20.8-30.65\% respectively. The hardness of these alloys was in the range of VHN 220-230. The Charpy impacts of these alloys were in the range 20-30 J. The microstructures of Fe-Al-Mn-xSi-C alloys were $\mathrm{x}$ phase containing $\alpha$ phase dispersion and were not modified after sensitization at $1000^{\circ} \mathrm{C}$ for 60 minutes.
\end{abstract}

Keywords: sensitization; as cast Fe-Al-Mn-xSi-C alloys, mechanical properties, sensitization behavior

\section{Introduction}

New design concepts for the construction of advanced lightweight ground transportation systems, such as automotive vehicles, including heavy haul trucks, electric trains, and cargo ships are basically oriented on economical and ecological requirements. These are a considerable reduction in weight, in fuel consumption, and in the emission of exhaust gases. Another important aspect is the increase of the specific efficiency-engine power per mass unit - of a vehicle. Newly developed lightweight steel based on ferritic iron aluminum alloys are showing promising physical, mechanical, and technological properties, such as high specific elastic stiffness and strength, excellent ductility and formability, reduced specific weight, and 
an improve corrosion resistance as well. ${ }^{[1]}$

Fe-Al-C alloy is a good candidate for replacing some of the conventional stainless steel in several applications at moderate to high temperature. ${ }^{[2]}$ (Huang and Froyen 2006). Fe-Al-C alloy is being developed for elevated temperature structural application up to $873 \mathrm{~K} \cdot{ }^{[3-5]}$ In addition, the plain iron-aluminum lightweight steel containing up to $9 \mathrm{wt}-\% \mathrm{Al}$ shows a reduction in density of $10 \%$ and more. ${ }^{[1]}$ On the basis of economic and lower density considerations, this material could be a good candidate for replacing some of the conventional stainless steel. ${ }^{[6-7]}$ Wherein, $\mathrm{Al}$ is used to replace the expensive alloy element $(\mathrm{Cr})$ in conventional $\mathrm{Fe}-\mathrm{Cr}-\mathrm{C}$ system. Ferritic iron aluminum alloys shows-promising physical and mechanical properties along with superior corrosion and oxidation resistance at much lower raw material cost. $^{[8]}$ Therefore it is suitable for development of new type of high strength lightweight steel. ${ }^{[1]}$

In contrast, $\mathrm{Fe}-\mathrm{Al}$ alloys exhibit poor toughness and brittle behavior at room temperature. ${ }^{[9]}$ Recent studies indicate that reduction in $\mathrm{Al}$ content to $8.5 \mathrm{wt}-\%$ resulted in enhanced ductility. Addition of carbon to Fe-Al containing 8.5 to 16 wt$\% \mathrm{Al}$ gives higher strength $^{[10]}$, and better machine ability. ${ }^{[11]}$ The addition of Manganese and carbon can stabilize the austenite phase and improve mechanical properties. ${ }^{[12]}$ In previous work, it has been shown that low carbon content $(0.05$ and $0.1 \mathrm{wt}-\%)$ in Fe-9 wt-\% Al leads low tensile ductility. ${ }^{[13]}$

Whereas, the ESR (Electro Slag Refined) ingots of Fe-10.5Al and Fe-13Al alloys containing high $(0.5$ and $1.0 \mathrm{wt}-\%)$ carbon exhibit excellent hot workability. ${ }^{[14]}$ The Fe-10Al-30mn-C-Si alloy is reported to have good resistance to stress corrosion cracking (SCC) in the sea water (corrosion rate lower than stainless steel SS 321 (Fe$18 \mathrm{Cr}-9 \mathrm{Ni}-\mathrm{Ti})$ ). This is due to the levels of $\mathrm{Si}$ of the Fe-10Al-30mn-C-Si alloy (1\% $\mathrm{Si})$.SiandNbis astrongstabilizerstructureDO3 $(\mathrm{Fe} 3 \mathrm{Al}) .{ }^{[14]}$ Sensitization is a serious problem for conventional stainless steel with high $\mathrm{C}$ content. While the sensitization study of $\mathrm{Fe}-\mathrm{Al}$ alloy with high $\mathrm{C}$ content has not been reported until now.

In this study, mechanical properties and the sensitization behavior of $\mathrm{Fe}-\mathrm{Al}-\mathrm{Mn}$ Si-C alloy have been reported.

\section{Experimental procedure}

Thirty five kilograms of $\mathrm{Fe}-\mathrm{Al}-\mathrm{Mn}-\mathrm{Si}-\mathrm{C}$ was prepared from mild steel scrap, high purity aluminum, and $\mathrm{Fe}-\mathrm{Mn}$ with medium $\mathrm{C}$. The alloy was prepared in an induction furnace under argon atmosphere. Molten metal is poured into sand molds to form ingots. The chemical compositions of ingots are listed in Table 1. The ingots were cut using bimetallic band saw blade to make the test specimens. Tensile test specimens were cut based on JIS 2201 standard. The Vickers hardness specimens were made on longitudinal sections of ingots. The Impact Charpy specimen of $3 \mathrm{~mm} \times 10 \mathrm{~mm} \times 55$ $\mathrm{mm}$ with $2 \mathrm{~mm}$ v-notch based on JIS Z 2242 standard. Temperature transition were observed at $-200,-100,0,-100,-200$. The density and sensitization specimens were made on cylinder block with $14 \mathrm{~mm}$ diameter and $10 \mathrm{~mm}$ height.

The sensitization specimen was heated at $1000^{\circ} \mathrm{C}$ for 60 minutes. The sensitized specimens were examined by optical and electron microscope. The phases present in 
the specimens were identified byX-ray diffraction technique. A copper target with nickel filter and a graphite single crystal monochromater were used to record the diffraction pattern.

The surface of the microstructure specimens were mechanically polished with abrasive paper up to 1200 grit, after surface finishing. The last mechanical polishing was done with $0.5 \mu \mathrm{m}$ alumina paste. The polished section were subsequently etched with $3.3 \% \mathrm{HNO}_{3}-3.3 \% \mathrm{CH}_{3} \mathrm{COOH}-0.1 \% \mathrm{HF}-93.3 \% \mathrm{H}_{2} \mathrm{O}$ by volume for micro structural examination by optical microscope.

Table 1. Chemical composition (wt-\%) of the alloys tested

\begin{tabular}{|c|c|c|c|c|c|c|c|}
\hline Alloys & $\mathrm{Al}$ & $\mathrm{Mn}$ & $\mathrm{C}$ & $\mathrm{Si}$ & $\mathrm{P}$ & $\mathrm{S}$ & $\mathrm{Fe}$ \\
\hline $\mathrm{A}$ & 7.5 & 5 & 0.55 & 0.5 & 0.02 & 0.01 & Bal. \\
\hline $\mathrm{B}$ & 7.5 & 5.25 & 0.6 & 0.1 & 0.03 & 0.01 & Bal. \\
\hline $\mathrm{C}$ & 7.45 & 5.1 & 0.6 & 0.15 & 0.03 & 0.02 & Bal. \\
\hline
\end{tabular}

\section{Results and Discussion}

\section{Mechanical Properties}

Table 1 shows the mechanical properties of as cast Fe-Al-Mn-Si-C alloys. The as cast $\mathrm{Fe}-\mathrm{Al}-\mathrm{C}$ alloys have superior tensile strength (617.78-695.56 MPa), elongation (20.8$30.65 \%)$ and hardness $(220-230 \mathrm{VHN})$. Figure 1 shows that the tensile strength and elongation of the as cast $\mathrm{Fe}-\mathrm{Al}-\mathrm{C}$ alloys increase with increasing $\mathrm{Si}$ content. The increase in tensile strength and the decrease in elongation of the as cast Fe-Al-Mn-Si$\mathrm{C}$ alloys with increasing $\mathrm{Si}$ content from 0.5 to $1.5 \mathrm{wt}-\%$ were significant. Asit has been reported that the addition of $2 \% \mathrm{Si}$ shown to increase the tensile strength ofFe1.5Al-0.7C alloy (Baligidad, 2007).

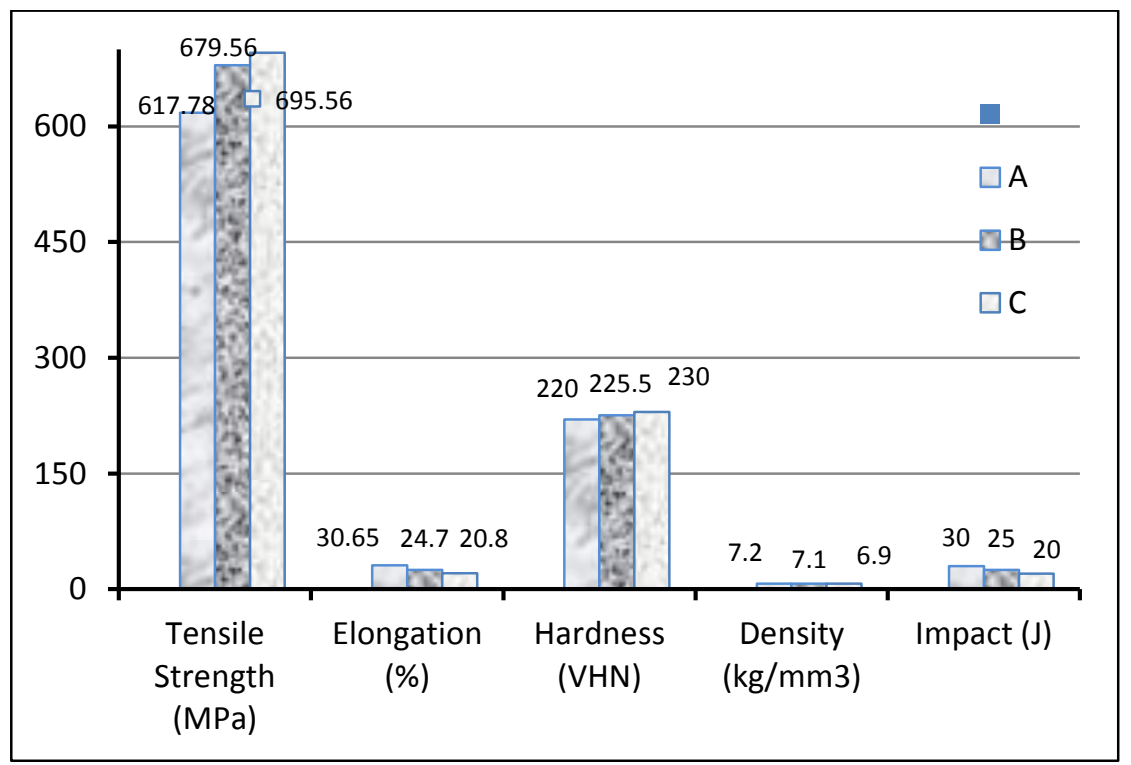

Figure 1. Mechanical properties of as cast Fe-Al-Mn-xSi-C lightweight steel 


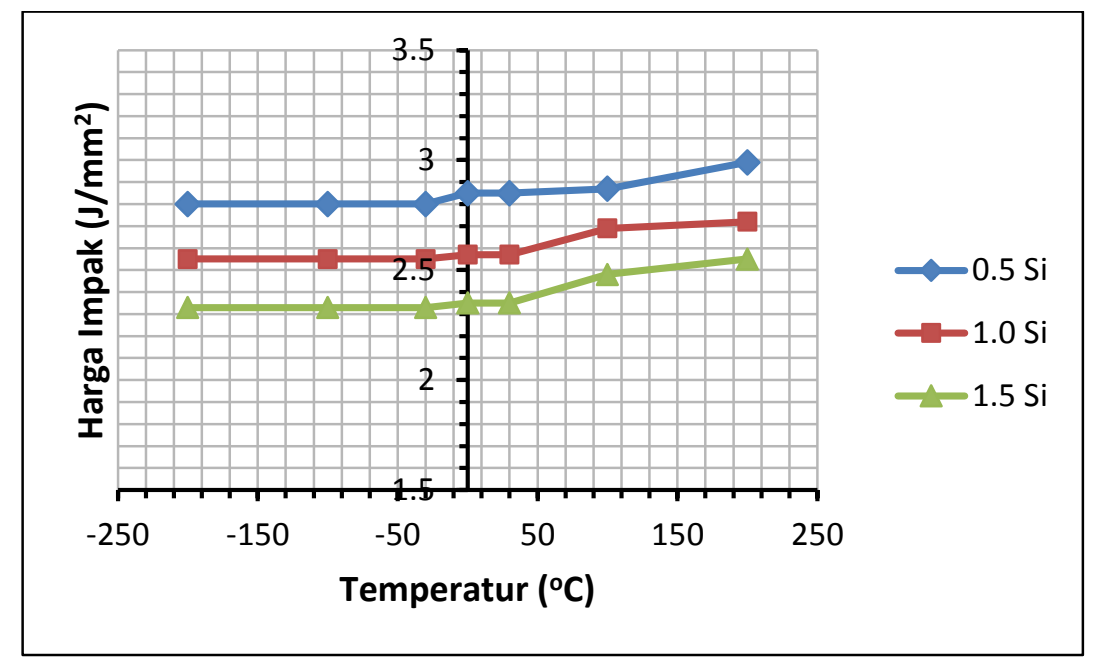

Figure 2. Impact value of as cast Fe-Al-Mn-Si-C lightweight steel

Table 1. Mechanical properties of as cast Fe-Al-Mn-Si-C lightweight steel

\begin{tabular}{|c|c|c|c|c|c|}
\hline Alloy & $\begin{array}{c}\text { Tensile Strength } \\
\mathrm{MPa})\end{array}$ & $\begin{array}{c}\text { Elongation } \\
(\%)\end{array}$ & $\begin{array}{c}\text { Hardness } \\
(\mathrm{VHN})\end{array}$ & $\begin{array}{c}\text { Density } \\
\left(\mathrm{kg} / \mathrm{mm}^{3}\right)\end{array}$ & $\begin{array}{c}\text { Impact } \\
(\mathrm{J})\end{array}$ \\
\hline $\mathrm{A}$ & 617.78 & 30.65 & 220 & 7.2 & 30 \\
\hline B & 679.56 & 24.7 & 225.5 & 7.13 & 25 \\
\hline $\mathrm{C}$ & 695.56 & 20.8 & 230 & 7.07 & 20 \\
\hline
\end{tabular}

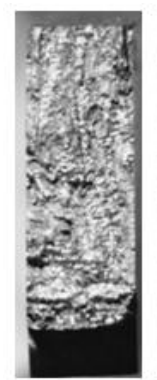

$-200^{\circ} \mathrm{C} \quad-100^{\circ} \mathrm{C}$

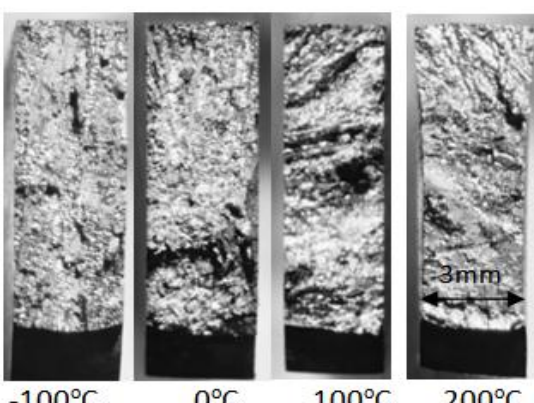

a. $0.5 \% \mathrm{Si}$

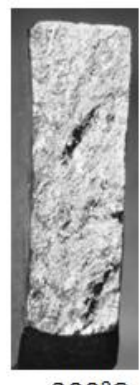

$-200^{\circ} \mathrm{C}$

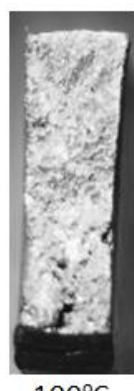

$-100^{\circ} \mathrm{C}$

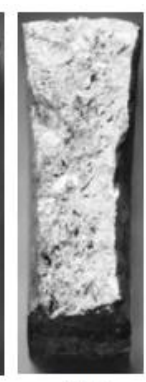

$0^{\circ} \mathrm{C}$ c. $1.0 \% \mathrm{Si}$

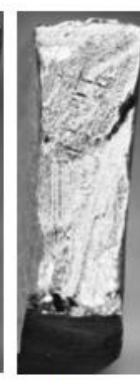

$100^{\circ} \mathrm{C} \quad 200^{\circ} \mathrm{C}$

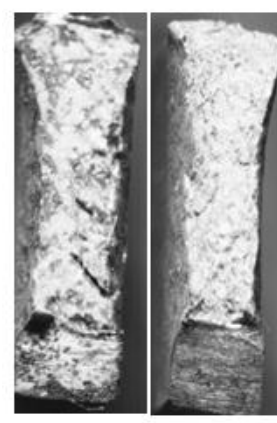

$-200^{\circ} \mathrm{C} \quad-100^{\circ} \mathrm{C}$

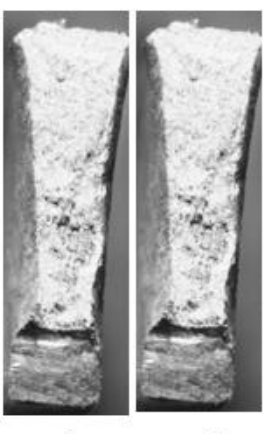

$0^{\circ} \mathrm{C} \quad 100^{\circ} \mathrm{C} \quad 200^{\circ} \mathrm{C}$

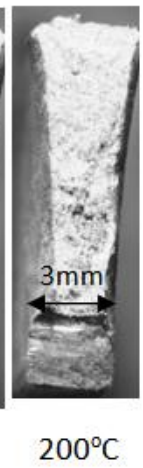

a. $0.5 \% \mathrm{~S}$

Figure 3. Macrograph surface fracture of the as cast Fe-xAl-0.6C lightweight steel 
The increasing Si content cause forming of Fe3Al (DO3 structure) which has ductile feature ${ }^{[14]}$, that caused increasing the tensile strength and decreasing of the elongation of the as cast Fe-Al-Mn-xSi-C alloys. The increasing of Si content from 0.5 to $1.5 \mathrm{wt}-\%$ of the as cast $\mathrm{Fe}-\mathrm{Al}-\mathrm{Mn}-\mathrm{xSi}-\mathrm{C}$ alloys also cause decreasing of density significantly but it has no significant influence to the impact toughness at room temperature down to $-200^{\circ} \mathrm{C}$. Transition curve as castFe-Al-Mn-C-xSi alloys is horizontal approach. It means the impact value of these alloys relatively stable at the temperature range of $-200^{\circ} \mathrm{C}$ to $200^{\circ} \mathrm{C}$. Theincreased levels of $\mathrm{Si}$ content decrease impact valuesuntil $30 \%$. This can be seen on the fracture surface where the influence of the levels of $\mathrm{Si}$ looks quite significant in fracture patterns. On the contrary, increasing Si content caused increasing hardness of these alloy significantly. Increase in $\mathrm{Si}$ content due to increased formation ofFe3Alis the main reason for this phenomenon.

\section{Sensitization}

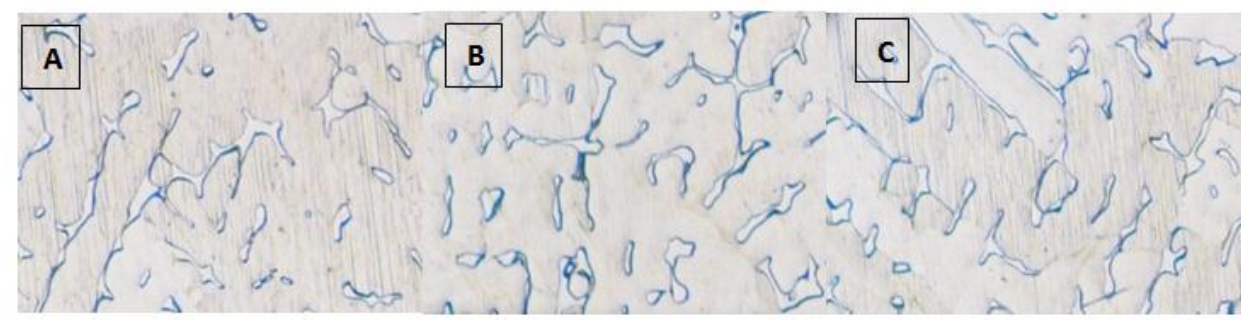

a. As cast Fe-Al-Mn-Si-C alloy

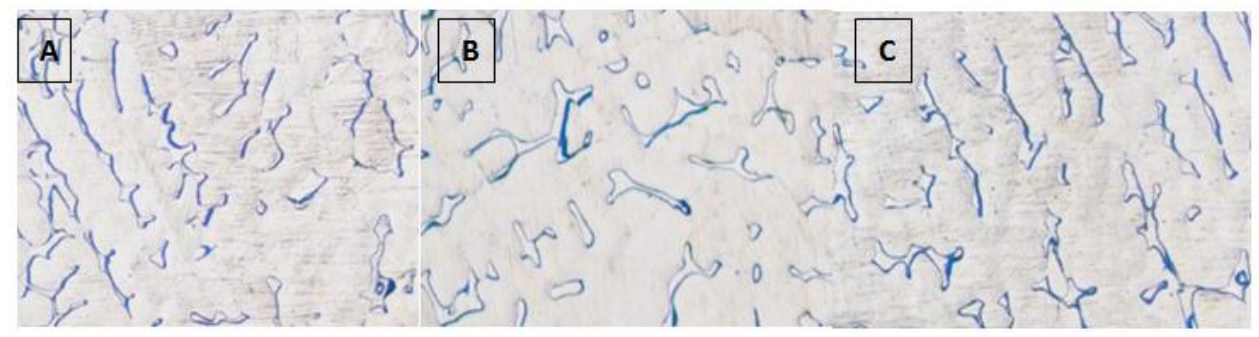

b. as cast Fe-Al-Mn-Si-C alloy after sensitization

Figure 4. Microstrusture of Fe-Al-Mn-Si-C alloy A. $0.5 \%$ Si, B. $1.0 \% \mathrm{Si}, \mathrm{C} .1 .5 \% \mathrm{Si}$

Figure 4 shows the optical microstructure of Fe-Al-Mn-Si-C as cast and after sensitization. The microstructure of as cast Fe-Al-Mn-Si-C Alloys(Fig.4a) were $\mathrm{r}$ phase (austenite structure) containing $\alpha$ phase (ferrite structure) dispersion. There are similar pattern in all three $\mathrm{Si}$ composition. Increased levels of $0.5-1.5 \% \mathrm{Si}$ is to give effect to an increase in the amount offerriteandFe $3 \mathrm{Al}$ phases. In figure4asaw an increase in ferrite phase however do not significantly. In figure 4 blooked no significant differences in the structure of the three compositions after the heating process at a temperature of $1000^{\circ} \mathrm{Cfor} 1 \mathrm{hr}$. The shape, size and number of phases of Fe- 
$\mathrm{Al}-\mathrm{Mn}-\mathrm{Si}-\mathrm{C}$ alloy are relatively the same as cast alloys. The elements of $\mathrm{Si}$ as ferrite stabilizer does not seem to affect significantly increase the range of $0.5-1.5 \% \mathrm{Si}$ after the heating process. Although not significant, the addition of ferrite phase was seen with an increaseof0.5-1.5\% Si. XRD test results indicate similar phase in both as cast $\mathrm{Fe}-\mathrm{Al}-\mathrm{Mn}-\mathrm{Si}-\mathrm{C}$ and after heating alloys.
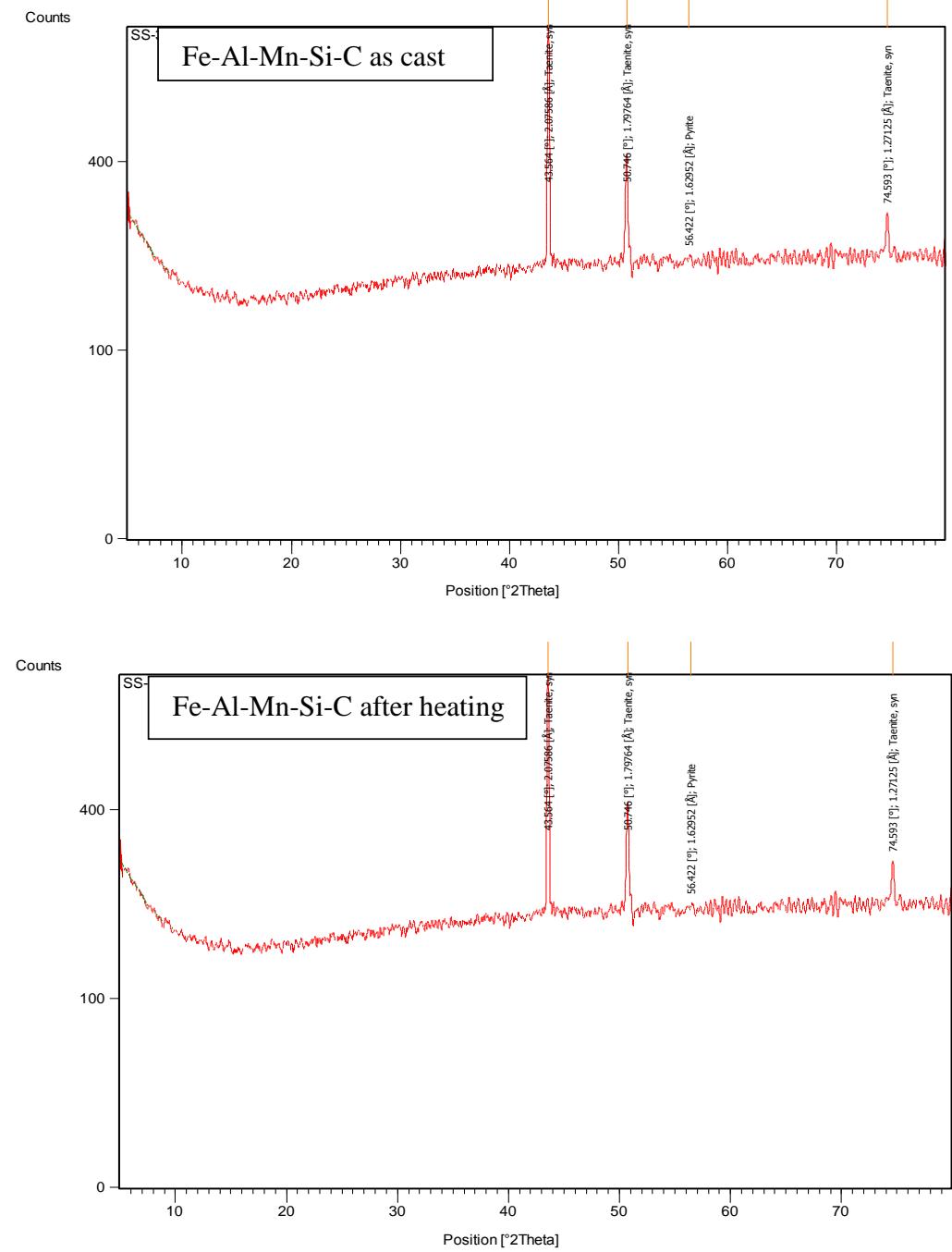

Fig 5. X-ray diffraction pattern of as cast $\mathrm{Fe}-\mathrm{Al}-\mathrm{Mn}-\mathrm{Si}-\mathrm{C}$ and after heating alloys

Peak that appears in the same position with the same relative intensity is the intensity of the austenite phase. So, detected phase is austenite phase.

\section{Conclusions}

The mechanical properties of as cast Fe-Al-Mn-Si-C alloys such as the ultimate tensile test (UTS) and elongation of these alloys were in the range (617.78-695.56 
$\mathrm{MPa}$ ) and 20.8-30.65\% respectively. The hardness of these alloys was in the range of VHN 220-230. The Charpy impacts of these alloys were in the range 20-30 J.

The microstructures of Fe-Al-Mn-xSi-C alloys were $\gamma$ phase containing $\alpha$ phase dispersion and were not modified after heating at $1000^{\circ} \mathrm{C}$ for 60 minutes.

\section{Acknowledgements}

The authors are pleased to acknowledge the financial support of this research by the Hibah Bersaing Program, Dirjen Dikti, Kementrian Pendidikan dan Kebudayaan.

\section{REFERENCES}

[1] Frommeyer, 2000, Physical Mechanical PropertiesIron-Aluminum-(Mn-Si) Lightweight Steels, The 1999 ATS International Steelmaking Conference, Paris. Sec.4.

[2] Huang, B.X., Wang, X.D., Rong,Y.H., Wang, L., and Jin, L., 2006, Mechanical Behavior and Martensitic Transformation of an Fe-Al-Si-Al-Nb Alloy, Materials Science and Engineering A, Vol. 438-440, p. 306-311.

[3] C.G. McKamey, J.H. Devan, P.F. Tortorelli and V.K. Sikka, 1991, A Review of Recent Development in Fe3Al-based Alloys, Journal of Materials Research., 6, pp. 1779-1805.

[4] V.K. Sikka, S.Viswanathan and C.G. McKamey, 1993, Development and Commercialization status of Fe-3Al-based Intermetallic Alloys', (ed. R. Darolia et al.), Warrendale, PA, TMS., pp. 483-491.

[5] U. Prakash, R.A. Buckley, H. and C.M. Sellars, 1991, Structure and Properties of ordered Intermetallics Based on the Fe-Al system, ISIJ International., 31, pp. 1113-1126.

[6] J.S. Dunning, M.L. Glenn, and H.W. Leavenworth, 1984, Subtitutes for Chromium in Stainless Steel, Metal Progress., vol. 126, No.5, pp. 19-24.

[7] W.C. Cheng, Y.C. Lin, and C.F.Liu, 2003, The Fracture Behaviors in an Fe-AlMn alloy During Quenching Processes, Material Science and Engineering, A343 (1-2), pp. 28-35.

[8] Kobayashi S, Zaefferer S, Schneider A, Raabe D, and Frommeyer G 2005 Intermetallics 13 1296-1303.

[9] Jablonska M, Rodak K, and Niewielski G 2006 Journal of Achievements in Materialsand Manufacturing Engineering Vol. 18 Issue 1 107-110.

[10] Baligidad RG, Prakash U, Ramakrishna Rao V, Rao PK, and Ballal NB 1996 ISIJ Vol. 36 No. 12 1453-1458.

[11] Baligidad RG, Prakash U, and Radha Krishna 1998 Metrans A Vol. 249 No. 12 97-102.

[12] Banerji, S.K., 1982, The 1982 Status Report on Fe-Mn-Al Steel, Foote Mineral Co, Exton.

[13] N.S. Stollof and C.T. Liu, 1994, Environmental Embrittlement of Iron Aluminides, Intermetallics, 2, pp. 75-87. 
[14] R.G. Baligidad and K Satya Prasad, 2007, Effect of Al and C on structure and Mechanical Properties of FMater. Fe-Al-C alloys, Journal of Materials Science and Technology., 23, 1, pp. 38-44.

[15] Morris, D.G., Munoz Morris, M.A., dan Requejo, L.M., 2007, Working Hardening in Fe-Al Alloys, Materials Science and Engineering. A, Vol.460461, p. 163-173. 